\title{
Wages, Employment and Trade Unions in Pakistan
}

\author{
MUHAMMAD IRFAN*
}

\begin{abstract}
In this paper, an attempt has been made to analyse the industrial workers' wages, in large-scale manufacturing, in the context of interaction between institutional and non-institutional forces. The growth in the real wages of industrial workers, unionization and employment are explained in the framework of a simultaneous-equation estimation. The study finds that Pakistan's data are suggestive of an interdependence between the real wage gains and the extent of unionization. Trade unions exert an upward pressure on wages but rising wages in turn facilitate unionization.
\end{abstract}

That employment-generation has lagged behind the growth in output and investment in the manufacturing sectors of the developing countries can hardly be disputed in the light of the evidence accumulated during the past two decades. Factor price distortions, specifically rising real wages of the industrial workers, have been offered as major explanations for the unsatisfactory performance and low labourabsorption capacity of manufacturing industries in the underdeveloped world. This inference is based on 'elasticity optimism' engendered by production functions estimated for many developing countries. Besides the conceptual and empirical problems involved in the estimation of the production functions, these studies tend to be highly aggregative and fail to reckon with the forces involved in a joint determination of wages and employment.

In contrast with the studies on the allocative role of wages, wage behaviour over time and its determinents are relatively less thoroughly explored in the literature. An investigation of this kind is important because the analysis of the rising real wages - a phenomenon observed in most of the developing countries - affords an identification of factors operating on wage structure, thereby yielding policy-relevant

* The author is Senior Research Economist at the Pakistan Institute of Development Economics (PIDE), Islamabad. Part of this paper is based on his Ph. D. thesis completed at Cornell University, USA. The author is also grateful to his thesis adviser, Walter Galerson, and members of thesis advisory committee, Erik Thorbeck and Ronald G. Ehrenberg for their guidance. The author wishes to thank Professor Syed Nawab Haider Naqvi, Director of the PIDE, for his help in improving the analysis and the exposition of the paper. Any errors or omissions are, however, the sole responsibility of the author. 
insights. The few research studies that did attempt to explain changes in real wages in the Third World hardly yielded consistent conclusions regarding the sources of rise in real wages.

Turner and Jackson [28], Berg [4], Kilby [12] and Knight [13] attributed improvement in real wages in various African countries to institutional forces, especially the government. On the other hand Ramos [21] has suggested rising skill level as one of the explanatory variables responsible for improvement in real wages in Latin America. Richard Webb [29] thinks that the whole question of policy-versus market is irrelevant, and has argued that the source of wage increase is clearly an interaction between the market and the non-market forces.

Most of these studies fail to incorporate the influence of agricultural growth on the real wages of industrial workers. Similarly, in most cases the role of trade unions in influencing changes in the industrial real wages has been assumed away. It has often been maintained that trade unions have no independent effect on wages - an assertion made plausible by surplus-labour models.

In this paper an attempt is made to ascertain the influence of agricultural growth on the real wages of industrial workers. In addition, trade unions are explicitly incorporated in our analysis. Using data on Pakistan's large-scale manufacturing for 1949-69, a set of three simultaneous equations is estimated wherein real wage changes, growth in unionization and industrial employment are jointly determined. The model is discussed in the Section I, while the results are reported in Section II. Policy Implications and Concluding Remarks make up Section III. The relevant data are explained in the Data Appendix.

\section{INTERDEPENDENCE BETWEEN GROWTH RATES IN TRADE UNIONISM AND REAL WAGE AND EMPLOYMENT}

Whether trade unions in developing countries have an independent effect on the real wages of industrial workers or not has been a matter of controversy. Evidence from the developed countries shows a positive association between a rise in union militancy and wage increase. However, quite a few studies, using econometric models of aggregate union growth, postulate the reverse relation as well: changes in real wages as one of the variables contributing to union growth. Since on a priori grounds, one can argue for both of these hypotheses, a proper procedure would be to specify a model that allows for interdependence between union growth and changes in real wage. Similarly, industrial employment and wages are joint outcome of the employers' decisions. This study attempts within a simultaneous-equations framework to explain changes in industrial employment, unionism and real wages. The model in the deterministic form is given below.
1. $\dot{\mathrm{W}}=\mathrm{a}_{1}+\mathrm{a}_{2}(\mathrm{~T} / \mathrm{E})+\mathrm{a}_{3}(\dot{\mathrm{V}} \mathrm{M})_{-1}+\mathrm{a}_{4}\left\{\delta\left(\frac{\dot{\mathrm{V}} \mathrm{A}}{\mathrm{LA}_{-1}}\right)\right\}+\mathrm{a}_{5} \dot{\mathrm{W} L}$

2. $(\mathrm{T} / \mathrm{E})=\beta_{1}+\beta_{2} \dot{\mathrm{W}}+\beta_{3} \dot{\mathrm{W}}_{-1}+\beta_{4} \dot{\mathrm{E}}+\beta_{5}(\mathrm{~T} / \mathrm{E})_{-1}+\beta_{6} \mathrm{AL}$

3. $\dot{\mathrm{E}}=\gamma_{1}+\gamma_{2} \dot{\mathrm{W}}+\gamma_{3}(\mathrm{~V} \dot{\mathrm{M}})_{-1}+\gamma_{4}\left\{\delta\left(\frac{\dot{\mathrm{V}} \mathrm{A}}{\mathrm{LA}_{-}}\right)\right\}+\gamma_{5} \mathrm{E}_{-1}+\gamma_{6} \mathrm{t}$ where

(W) = Real wages of industrial workers;

$(\mathrm{T} / \mathrm{E})=$ Unionization - trade union membership divided by industrial employment;

$(\mathrm{VM})=$ Value added in large-scale manufacturing at constant price of 1959-60;

$(\mathrm{WL})=$ Product of the percentage of industrial workers covered by the minimum wage legislation and the legal minimum wages, deflated by cost of living index;

$(\mathrm{VA} / \mathrm{LA})=$ Agricultural productivity - value added in agriculture at constant prices of 1959-60 divided by employment in agriculture;

$\delta \quad=\quad$ Threshold variable - taking the value of 1 whenever $\left(\frac{\dot{\mathrm{VA}}}{\mathrm{LA}}\right)>$ [0.02] and zero otherwise;

$\mathrm{E}=$ Industrial employment;

$\mathrm{AL}=$ Dummy variable to reflect government intervention taking the value of 1 for the year when government measures suppressed unions activity; and

$\mathrm{t}=$ Variable for time trend.

Dots on W, E and (T/E) etc. are proportionate changes of these variables. Each of these equations is explained below.

\section{Equation No. 1: Determinants of Growth in Manufacturing Wages}

Wage changes are hypothesised to be positively affected by changes in manufacturing output, agricultural average product, unionization and minimum wage legislation. The first two factors can be regarded as market forces and the other two as institutional forces operating upon the level of real wages. Admittedly, the demarcation line between the market and non-market forces is thin. In this paper, proportionate change in manufacturing output (VM) is used to simulate shifts in the demand for labour due to increased output. This variable (VM) is, however, lagged by one year because decisions regarding the level of employment are often made well in advance and the bonus payments to individual workers are generally made after annual accounts of the firms are closed. 
A change in average agricultural productivity, ${ }^{1}$ working through factors and product market interdependencies, is likely to have two mutually reinforcing effects on industrial wages. First, a rise in agricultural productivity may restrain migration to urban areas by creating demand for labour within the agriculture sector. This may shift leftward the supply schedule in the urban labour market. Secondly, since a growth in average income in agriculture increases the demand for industrial products, the demand schedule for industrial labour will be shifted rightward. However, the net effect of these shifts in the supply and demand schedules on industrial wages will vary with the distribution of income in agriculture sector and the degree of governmental intervention in the determination of industrial wages.

Government intervention is generally considered a major factor influencing wages in the developing countries. It is, however, difficult to devise an appropriate proxy which captures the totality of the effects of state intervention on wages. State can influence directly at plant level through industrial courts; it may affect the wage structure indirectly in the industrial sector by changing wage scales of its own employees. Minimum-wage legislation represents another measure which has a direct bearing on wages in the manufacturing sector. This study is confined to assessing the impact of minimum-wage legislation on manufacturing wages. In the estimation procedure used, the variable of minimum-wage legislation (WL) is represented by a product of the percentage of industrial workers covered by wage legislation and the legal minimum wages, deflated by cost-of-living index.

Wage equation (1) has been specified in the light of the conjectures offered by the dualistic models of Lewis [14] and others wherein agricultural average product has been regarded as supply price of urban labour. ${ }^{2}$ In this equation some of the important variables, however, have not been reckoned with. Since our analysis is confined to average wages in large-scale manufacturing which may vary with a compositional shift in the manufacturing industries and/or changes in the skill of the work force, any attempt to explicitly incorporate these factors is precluded by lack of data.

\section{Equation No. 2: Determinants of Unionization}

We have used changes in the level of unionization $(\mathrm{T} / \mathrm{E})$ as a dependent variable in our estimation. However, actual union membership (T) is preferable to the level of unionization (T/E) for explaining trade union growth if the employment or potential union membership does not vary widely during the period under analysis.

${ }^{1}$ Curiously enough, the majority of research studies on manufacturing wages in the developing world failed to incorporate agricultural productivity as one of the explanatory variables.

${ }^{2}$ The relationships between the average product in agriculture and urban wages postulated by these models are, however, demonstrated to be quite restrictive [25] and [30].
This requirement cannot be satisfied in a developing country like Pakistan, where employment more than doubled during the period under enquiry. Furthermore, the level of unionization $(\mathrm{T} / \mathrm{E})$ is assumed to reflect the level of union militancy and has been specified as a determinant of wage changes by both Hines and Ashenfelter. ${ }^{3}$ To the extent that we are concerned with an explanation of real wage changes associated with union militancy, a change in the level of unionization is a more relevant proxy than changes in trade union membership.

Changes in real wages, both current $(\mathrm{W})$ and lagged by one year $(\mathrm{W})_{1}$, are used as explanatory variables to estimate their "credit effect" on the growth of unionization in Pakistan. Government measures - e.g. the ban on strikes during the imposition of Martial Law (1958-59), the suspension of fundamental rights during the war with India (1965-66), and the banning of the Communist Party which had a substantial following in the labour movement (1953-54) - presumably have had adverse repercussions on union growth. The effect of these factors on union growth is assessed by using a dummy variable $(\mathrm{AL})$ which takes the value of one in these years and of zero in other years. Since there are hardly any reliable data on the rate of unemployment in Pakistan, the proportionate changes in the employment ${ }^{4}$ of factory workers (E) are used, following Ashenfelter, to ascertain the effect of this potential union membership growth (E) on the growth in the level of unionization $(\mathrm{T} / \mathrm{E})$.

The specification of this equation has been based on the empirical studies conducted in other countries. Econometric models of union growth have been used by Hines for UK [9], Ashenfelter and Pencaval for the US [2] and Sharpe for Australia [23]. A critical evaluation of these studies is given in the study by George S. Bain and El Sheikh [3], wherein the real wages, the level of unionization, and a measure of unemployment or employment emerge as major explanatory variables of the trade union growth. Mutual dependence between trade union growth and wage gains has also been assessed by Ashenfelter [1] and Hines [6]. Since they use changes in retail prices as a proxy for real wage changes, their estimation procedure

${ }^{3}$ Due to the multicollinearity introduced by (T/E) Ashenfelter dropped it and used $(\mathrm{T})$ in actual estimation. To that extent, his empirical procedure is misspecified.

${ }^{4}$ It may be recalled here that this use of variable (E) has been criticized by Mancke [15] who termed it "nearly definitional due to union security provisions". George S. Bain and El Sheikh [3] are also critical of its use because (E) has more than one effect - e.g. the growth in potential union membership, the labour market tightness, and changes in the employment distribution between high and low union density sector. Hence the lumping of these three different effects into a single variable $(\mathrm{E})$ is considered inappropriate. Ashenfelter provides a cogent defence with regard to the first criticism by maintaining that there is no reason why a given change in potential union membership (E) should automatically produce the same proportionate change in actual union membership $(\mathrm{T})$. The second set of criticism still remains unanswered. 
fails to reckon with the "credit effect" study, real wages are explicitly introduced to assess the "credit effect" as well as to infer about the interdependence between the growth of union power and real wage gains.

Departing from the earlier studies on the subject, the retail price index is not used in this study as an explanatory variable of the trade union growth. Price rises are considered to be conveying a kind of "threat effect" (rising prices may be perceived by workers as a threat to their living standard) and a "prosperity effect" (price rises may indicate the general prosperity of industry). Both these effects are assumed to have a unidirectional impact: a positive association between the change in retail price and the changes in trade union membership, because workers tend to organize to protect their living standards and the employers acquiesce in workers' demands for better conditions and union recognition in periods of inflation. The reverse, therefore, may hold in recessionary conditions.

To the extent that workers aim at improving their living standards, real wage appears to be a more appropriate explanatory variable for union growth than changes in price level. In Pakistan, roughly one-third of the workers' compensation, such as housing and medical facilities is paid in kind. This acts, however, as a cushioning device in the wake of rising prices and results in a diminution of the threat effect. The prosperity effect ${ }^{6}$ of the rising prices may not have an unambiguous relation with union growth. A concession by employers may result in a reduced eagerness of the workers to organize or join trade unions, i.e. a defensive organization.

The expected positive association between changes in the general price level and changes in union membership are not borne out universally. Sharpe [23] finds a reverse association in the case of Australia. The finding in other studies - that price rises do not have a clear impact on union growth - is explained in terms of ad hoc rationalization: "high rates of inflation tend to numb people's sensitivity to price rises" [3]. In preliminary exercises, we found that price (cost-of-living index) fails to improve the fit of Equation 2. To make things worse, it also introduces multicollinearity. The price change variable is, therefore, excluded from the equation.

\section{Equation No. 3: Determinants of Industrial Employment}

The demand for labour depends on the level of output and the factor price ratio. Besides these forces, which determine long-run optimal capital/labour mix, there are short-term factors such as capacity utilization. In our regression exercise, employment changes are hypothesized to be explained by changes in real wages (W) and value added in large-scale manufacturing (VM).

${ }^{5}$ Workers credit the unions for a rise in their wages, which in turn facilitate unionization.

${ }^{6}$ Stagflation of the 1970 s would, however, question the existence of prosperity effect of
The appropriate lag of an employment function is difficult to determine a priori. We could not follow the earlier studies which used stock adjustment process because an addition of lagged changes in employment to the list of independent variables introduces serious multicollinearity. Hence past year's level of employment (W) -1 was used instead. Furthermore, time trend and changes in average agricultural productivity are also added to assess their effect on industrial employment. Average agricultural productivity in the employment function should capture the influence of rising supply price of industrial labour on its employment. Non-availability of reliable data on the price of capital precluded the incorporation of this important variable.

The equations were estimated using Two-Stage Least Square with Cochrane Orcutt procedure to take care of the serial correlation.

\section{RESULTS}

\section{Equation 1}

Two-thirds of the variance in real wage changes is explained by changes in trade union density $(\mathrm{T} / \mathrm{E})$, in value added in manufacturing $(\mathrm{VM})_{-1}$ and in minimum wage legislation $(\mathrm{W} / \mathrm{L})$. The average agricultural product variable bears the expected sign but is not significant (Table 1).

The positive influence of trade unions on wages in the presence of presumed urban unemployment needs explanation. There are reasons to believe that trade unions are not ineffective even in these circumstances. ${ }^{7}$ First of all, even when unemployment prevails, the queue at the factory gate is not very long; secondly, those outside the factory gate are not perfect substitutes of those inside. This is because the latter have "internalized the norm of a typical behaviour pattern of industrial social system" [26], which their counterparts, outside the gate, do not have. Furthermore, the cost of labour for the period under study (1949-69) averaged around one-third of the industrial output (value added). Besides, in the 'soft market' environment of Pakistan, wage cost may have been passed on to the consumers. Together, these factors tend to weaken the employers' resistence to union demands. Thus, the employed workers, who are a non-competing group, low labour costs and the sellers market for producers create a conducive atmosphere for union's positive effect on wages.

There are hardly any data available on union and employer agreements as these are not public documents in Pakistan. One can only draw inferences about the strength of collective bargaining from the cases referred to the industrial courts for

${ }^{7}$ Changes in trade union density $(\mathrm{T} / \mathrm{E})$ can have a spurious positive correlation with changes in average wages if: (1) workers move from non-union to unionized sector keeping constant the union/non-union wage differential; and/or the union/non-union wage differential increases over time. Both the changes, however, reach a limit very soon. See Ashenfelter and Pencaval [1]. 
adjudication. While in the 1950s only a few cases were referred to industrial courts, in the following decades, the number of such cases went up to thousands. However, around fourth-fifths of those cases were related to the disciplinary actions and promotions and very few cases pertained to claims for higher wages and bonuses. It can be argued that most of the wage settlements took place outside the courts through collective bargaining or conciliation machinery, which explains the mechanism of the union operation and pressure. The conclusion that trade unions had an independent and significant effect on industrial wages is, therefore, quite plausible.

The other significant variable in the wage equation, the manufacturing output growth (VM), can be related to a shift in the demand for labour and also reflects the firm's capacity to pay. The coefficient, which is the elasticity of wages with respect to output, is 0.72 . Gregory [8] conducted a similar exercise, wherein he regressed industrial real wage changes on per capita G.D.P. changes, using a sample of 36 developing countries and found the corresponding coefficient of the order of 0.83 . His estimation procedure is not exactly the same as adopted in our wage equation; nonetheless, it provides supporting evidence.

The minimum-wage legislation variable is marginally significant. For the twenty years under analysis, the minimum wage legislation was applicable to the years 1963-69; and even then it covered only a few industries, except for the last year of the period (1969), when the minimum wage regulations were extended to the entire manufacturing sector. Despite these factors the positive coefficient of this variable suggests that minimum wages did raise the average wage of industrial workers.

Because of the multicollinearity problem, average productivity in agriculture has turned out to be insignificant. ${ }^{8}$ A simple regression of changes in real wages on changes in average agricultural product shows that the latter explains one-third of the variance in the former. Its coefficient suggests that any change in the average agricultural product, above the threshold of 2 percent, changes industrial real wages in the same direction, by about 79 percent of its own change. 9 The rising agricultural productivity reflects the labour demand generated by a higher growth in agriculture which may restrain the flow of migrants to urban areas. In the employment equation, the coefficient of the variable is negative which supports the above explanation.

\section{Equation 2}

In the second equation, changes in union density (T/E) are significantly explained by the lagged changes in real wages $(W)_{-1}$, changes in employment $(E)$

${ }^{8}$ It must be noted that ' $t$ ' test is not strictly valid for the case of two-stage least-square estimation.

${ }^{9} \dot{\mathrm{W}}=0.02+.798\left(\frac{\dot{\mathrm{V}}_{\mathrm{A}}}{\mathrm{LA}}\right)$

(.96) $(1.44) \mathrm{LA}_{-1}$ 
and previous year's level of unionization $(\mathrm{T} / \mathrm{E})_{-1}$ (see Table 1). The dummy variable (AL), which reflects the effect of government intervention, is the only explanatory variable that fails to qualify the conventional significance test. Its coefficient is, however, of the expected sign. A positive influence of the changes in real wages (lagged by one year) on unionization bears out the "credit effect" of real wages on union growth. Similarly, the negative sign of the level of unionization (lagged by one year) on trade union growth reflects the saturation effect. Given the fact that approximately half of the workers in Pakistan's large-scale manufacturing are unionized the negative saturation effect appears plausible.

An inverse association between contemporaneous changes in employment and changes in union density, a result of our exercise, is not in conformity with earlier studies. The limited nature of the data on employment and unionization hardly affords an opportunity for an exhaustive search for non-linearities and lags involved in their relationship. However, in our preliminary exercises an addition of the level of employment lagged by one year $(\mathrm{E})_{-1}$ to the list of the above -mentioned explanatory variables, at the cost of added multicollinearity and one degree of freedom, yielded a result which implied that a higher level of employment leads to a rise in the rate of growth of unionization, of course with a lag. Why the contemporaneous changes in employment and unionization bear an inverse association still needs to be explained.

The observed inverse relationship between current changes in employment and unionization stems from the nature of unions and the pattern of employment growth in Pakistan. Trade unions in Pakistan are organized at the level of the plant, and not at the industrial level. A rise in employment will be reflected in higher union membership without any lag if employment is generated in the existing unionized plants. This has not been a normal pattern of employment growth: rather it occurred through the establishment of new plants. In the newly established plants, the emergence of an effective trade union may take more than a year or so - of course, depending on the organizational drive of the outside labour leadership. Thus a rise in industrial employment may not simultaneously lead to a rise in the union membership. Furthermore, the management of newly established plant often bids away the experienced worker from the old plants. This may represent an exodus from a unionized plant to a non-unionized plant. In these circumstances, it is possible to have a negative association between changes in employment and the level of unionization. The possibility of the observed relationship between changes in employment and unionization being supurious cannot be ruled out. As discussed in the Data Appendix, the reported employment figures contain erratic fluctuations.

\section{Equation 3}

The explanation of industrial employment is not very satisfactory. The significant variables are the time trend and previous year's level of employment itself.
The time trend is used as a proxy for the development of the economy, the ensuing structural changes and a host of other factors. The negative association between employment changes and lagged level of employment reflects the declining rates of employment generation owing to a variety of factors like capital deepening and the compositional changes of the industrial sector, from labour-intensive to capitalintensive (e.g. petrochemical) industries.

The introduction of the time trend as an explanatory variable leads to serious multicollinearity and renders the variables of wage changes and output growth insignificant, though their coefficients retain the expected signs. A simple regression of employment changes ${ }^{10}$ on real wage changes and output explains 20 percent of the variance. The coefficient of wage changes (significant at the 10-percent confidence level) is not much different from what Enkson finds $(0.83)$ for Latin American countries [7]. Employment sensitivity to wage changes is reflected by elasticity coefficient. It is interesting to note that Isbister [10] finds the output elasticity of demand for labour in the case of Mexico roughly equivalent to .62 estimated for this study. However, Stern estimates the corresponding coefficient at .40 for the whole of Latin America, which is less than ours. Since the estimation procedures, level of aggregation, and nature of economies are different, these results are not strictly comparable.

\section{POLICY IMPLICATIONS}

Several factors bear upon the policy relevance of this study. The study is based on Pakistan's experience of the Fifties and Sixties which may not be a relevant guide for the future. Moreover, data limitations do not permit an exhaustive search for the non-linearities and lags involved in the relationship between unionization and employment. Similarly, specification of the employment function is less than satisfactory. Notwithstanding these limitations, policy implications of this study are discussed below, in terms of the elasticity co-efficients.

The sensitivity of employment to wage changes and minimum-wage legislation is borne out by our results. The elasticity coefficients of these variables are, however, smaller than that of the past employment level itself and average product in agriculture. The negative coefficient of past level of employment is suggestive of an upper bound on employment creation occasioned presumably by lack of technological options and/or compositional changes in the manufacturing industries, making them less labour-intensive. A negative elasticity coefficient of average product in the agriculture sector reflects that agricultural growth, due to green revolution, may have generated higher demand for labour within agriculture, thereby raising the

$$
{ }^{10} \dot{\mathrm{E}}=-12+\underset{(1.01)}{.71} \dot{\mathrm{VM}}_{-1}-\underset{(-1.39)}{-0.62 \dot{\mathrm{W}}}
$$


labour supply price. It must be noted, however, that employment equation suffers from specification error as discussed earlier; hence, the above results need to be interpreted carefully.

The elasticity of wages with respect to output growth is higher than the data would substantiate. Nonetheless it does indicate a positive association between these two variables. Rising average product in agriculture creates demand for labour within agriculture and also checks rise in the prices of food items. Thus, it has a positive effect on real wages of the workers in large-scale manufacturing. Institutional variables like minimum-wage legislation and trade unions positively affect real wages of industrial workers. Their elasticity coefficients are of the lower magnitude than that of output growth and agricultural productivity. To the extent that the proxy used for measuring trade union strength (the level of unionization) is deficient, this result is subject to revision.

Table 2

Elasticity Co-Efficients

Elasticity Co-efficients

with respect to

OF

\begin{tabular}{|c|c|c|c|c|c|}
\hline $\begin{array}{l}\text { Manufac- } \\
\text { turing } \\
\text { output } \\
\text { lagged by } \\
\text { one year } \\
(\mathrm{VM})_{-1}\end{array}$ & $\begin{array}{c}\text { Agricul- } \\
\text { tural } \\
\text { Average } \\
\text { Product } \\
\text { one year } \\
\text { (VA/LA)_1 }\end{array}$ & $\begin{array}{l}\text { Minimum } \\
\text { Wage } \\
\text { Legislation } \\
\text { (WL) }\end{array}$ & $\begin{array}{l}\text { Wages } \\
\text { Lagged } \\
\text { by one } \\
\text { year } \\
\text { (W)_1 }\end{array}$ & $\begin{array}{c}\text { Employ- } \\
\text { ment } \\
\text { Previous } \\
\text { year } \\
(\mathrm{E})_{-1}\end{array}$ & $\begin{array}{l}\text { Level of } \\
\text { Unioniza- } \\
\text { tion Lagged } \\
(\mathrm{T} / \mathrm{E})_{-1}\end{array}$ \\
\hline
\end{tabular}

Employment .19
$-.24$

(-.72)

$-.08$

$-.11$

$-.09$

$-.17$

Wages

$+.68$

$$
+.11
$$

$(-.001)$

$(+.22)$

$+.16$

$+.20$

$(+.17)$

$(-.75)$

.05

Unionisation -.23

0.88

$+.14$

$+1.22$

$+.20$

$+.10$

$(+.03)$

Union

Membership -.12
$+0.1$

$+.99$

$+.32$
*Elasticity coefficients reported in this table are taken from different variants of estimating equations (see Appendix Table II. Moreover, two of the three equations are over-identified. We, therefore, get a range of values.
Level and membership of trade unions appear to be favourably influenced by rising agricultural productivity, wage rise and minimum-wage legislation. Workers' bargaining strength gets enhanced by agricultural growth either through accelerated bargaining strength gets enhanced by agricultural growth either throur in urban areas. A very high coeffi cient of wages suggests, through the credit effect, that workers tend to organize more in the wake of rising real wages.

On the basis of the above findings, wage rise can hardly be singled out for low labour-absorptive capacity in large-scale manufacturing. Wage restraint, therefore, may not succeed in creating substantial employment expansion. The effect of unionization on real wages of industrial worker appears low. However, given the level of aggregation of our study and the fact that unionization is hardly uniform across firms, the workers in the non-unionized establishments will be at a disadvantageous position vis-a-vis their counterparts in unionized firms. For the sake of promoting harmonious industrial relations, formation of trade unions and collective bargaining needs to be encouraged at the level of industry rather than at the firm level.

\section{CONCLUDING REMARKS}

This study suggests that during the 1949-69 period, the behaviour of the rea wages of industrial workers in Pakistan was influenced by both market and institutional forces. Rising average agricultural product was associated with expansion in agricultural employment, thereby arresting the flow of workers to urban areas, which in turn led to higher urban wages. A higher growth of manufacturing output also increased industrial wage because of the higher (derived) demand for industria labour. Minimum wage legislation has had a positive effect on the average wages of labour in large-scale manufacturing. A positive association between changes in the level of unionization and real wage changes reflects an interdependence between the two: real wages affect and, in turn, are affected by trade union growth.

Our empirical exercise suggests that besides real wages the growth in industria employment, the level of unionization already attained, and government interven tion have influenced the rate of growth in union density during the period unde analysis. Thus roughly the same set of variables constitutes the determinants of trade union growth in Pakistan and the western developed countries, despite diverse politico-economic conditions. Industrial employment was found to be inversely related to growth in real wages. It is difficult to quantify the job loss occasioned by the rise in real wages because the price of capital could not be incorporated in the analysis. Moreover, to the extent that the jobs in the tertiary sectors are related to the level of productivity in the manufacturing sector, the changes in its wage leve then simply perform intersectoral employment reallocation. Furthermore, the decelerating rate of growth in industrial employment may have been simply due to lack of technological options. 


\section{Data Appendix}

\section{Wages}

Wage data collected under the Payment of Wages Act 1936 by Ministry of Labour \& Social Welfare have been used for this analysis. Wages are reported only for workers, both production and non-production, who earn less than two hundred rupees per month. Average wage at the aggregate level of manufacturing sector has been arrived at by dividing the total wage bill with the number of workers. The perennial and seasonal industries are lumped together.

There appears to be some reporting errors for few years. For instance, the average wage registered an increase of roughly 25 percent in 1955 and of 30 percent in 1962. Similarly, there was a one-third decline in the average wage as compared to those in the previous years. These spurts may be due to erratic reporting in wage bill or employment or both.

Despite the fact that wage data are not exclusively related to an homogeneous category like production workers, and contain reporting error, we used them in the regression analysis as a last resort. Since these data refer to low-wage bracket, the changes in average wages will presumably approximate the changes in production workers' wages. No adjustment, like three-year moving average, is made for the reporting errors because it would have introduced a bias.

\section{Trade Union Membership}

Membership reported in the 25 Years of Pakistan in Statistics, 1947-1972 for the industrial categories of Textiles, Printing Presses, Food, Engineering, Beverages, Tobacco, Wood and Glass, Chemicals and Dyes, Leather and Rubber and Miscellaneous are added to arrive at the total union membership in large scale manufacturing. The reported membership, however, may diverge from the actual membership owing to non-reporting.

\section{Employment}

The Employment of factory workers reported in the above-mentioned source is used. It refers to factory workers only. There is no unique definition of a worker in the labour laws. Presumably, it covers the production workers and manual nonproduction workers. It is, however, exclusive of clerical and supervisory staff. The employment growth yielded by these data may under-estimate the actual growth in industrial employment if capital/labour substitution elasticity is higher for this category than the average. The data as reported possibly contain few reporting errors. For example, the employment reported for 1955 is half of the preceding and the following years. The reported employment, similarly, declines after 1963 until 1968. For 1969 it registers a 30-percent rise.

\section{Value Added in Large-Scale Manufacturing}

Khan and Bergan have given estimates of the gross value added in large-scale manufacturing for the period from 1949-50 to $1959-60$. For the subsequent period, the data are taken from the Economic Survey, 1974-75. The estimates of the period, the datue added are based on the Census of Manufacturing Industries, 1959-60 with an adjustment for the undercoverage and mis-reporting. For other years, the quantum index of manufacturing is applied to these bench-mark data for estimating the gross value added. The estimates of the gross value added in the national income accounts were revised in 1964-65 and 1969-70 because of the availability of improved estimates of the quantum index of production. The value added is reported for the fiscal year (July-June) and is averaged for two consecutive years to get the calendar year (common) figures for regression.

\section{Average Agriculture Product}

The value added data for agriculture (at constant factor cost of 1959-60) are divided by the employment in agriculture. The employment in agriculture is estimated on the basis of the population censuses of 1951 and 1961 and from the Labour Force Surveys of various years. The Censuses of 1951 and 1961 provide information on employment in agriculture for these two years. The annual compound growth rate, based on these two years, is used to estimate the employment in agriculture for the intervening years. The Labour Force Surveys, which provide information on the percentage distribution of the labour force in different sectors, are used to estimate the employment in agriculture for the 1963-69 period. The procedure used in employment estimation, however, assumes a yearly growth at a uniform rate during the 1950s. Similarly, for the period from 1963 onward the reliability of the estimated employment depends on the quality of the data reported in various labour force surveys.

\section{Minimum Wage Legislation}

This variable is the product of (a) the percentage of manufacturing employment covered by minimum laws; and (b) the minimum wages fixed (average of Lahore and Karachi zones). This is deflated by the cost-of-living index. During the 1963-68 period, few industries were covered by the Minimum Wage Legislation. Their share in the manufacturing employment is taken from the various Censuses of Manufacturing Industries. For 1969, however, the minimum wage is extended to the entire manufacturing sector.

The data used in the regression analysis are given in Appendix Table I. 
Regression Analysis Data

\begin{tabular}{|c|c|c|c|c|c|c|c|}
\hline Variable & $\begin{array}{l}\text { Trade Union } \\
\text { Membership } \\
\text { (in Thousands) } \\
\text { (T) }\end{array}$ & $\begin{array}{l}\text { Employment } \\
\text { Factory } \\
\text { Workers } \\
\text { (in Thousands) } \\
\text { (E) }\end{array}$ & $\begin{array}{l}\text { Value Added } \\
\text { in Large-Scale } \\
\text { Manufacturing } \\
\text { (in Million } \\
\text { Rupees) } \\
\text { (VM) }\end{array}$ & $\begin{array}{l}\text { Agriculture } \\
\text { Average } \\
\text { Product } \\
\text { Rupees } \\
\text { VL/LA }\end{array}$ & $\begin{array}{l}\text { Minimum } \\
\text { Wage } \\
\text { Rupees } \\
\text { (WL) }\end{array}$ & $\begin{array}{l}\text { Disciplinary } \\
\text { Measures } \\
\text { "Dummy" }\end{array}$ & $\begin{array}{c}\text { Real } \\
\text { Wages in } \\
\text { Rupees }\end{array}$ \\
\hline 1949 & 44.43 & 131.52 & 277 & 1094 & 0 & 0 & 803 \\
\hline 1950 & 50.54 & 123.76 & 342 & 1100 & 0 & 0 & 900 \\
\hline 1951 & 52.74 & 130.74 & 406 & 1043 & 0 & 0 & 944 \\
\hline 1952 & 45.34 & 151.85 & 502 & 976 & 0 & 0 & 894 \\
\hline 1953 & 35.96 & 186.91 & 646 & 1022 & 0 & 0 & 906 \\
\hline 1954 & 35.48 & 205.18 & 802 & 1063 & 0 & 1 & 954 \\
\hline 1955 & 45.29 & 120.98 & 942 & 1049 & 0 & 0 & 1251 \\
\hline 1956 & 45.84 & 213.53 & 1018 & 1052 & 0 & 0 & 1238 \\
\hline 1957 & 31.05 & 250.90 & 1068 & 1054 & 0 & 0 & 1116 \\
\hline 1958 & 31.53 & 297.42 & 1128 & 1063 & 0 & 1 & 1147 \\
\hline 1959 & 45.03 & 244.92 & 1159 & 1065 & 0 & 1 & 1075 \\
\hline 1960 & 66.66 & 224.52 & 1394 & 1045 & 0 & 0 & 1187 \\
\hline 1961 & 94.20 & 286.61 & 1671 & 1070 & 0 & 0 & 1088 \\
\hline 1962 & 72.32 & 285.52 & 1934 & 1095 & 0 & 0 & 1515 \\
\hline 1963 & 113.81 & 322.00 & 2233 & 1098 & 34.6 & 0 & 1184 \\
\hline
\end{tabular}

Appendix Table I - (Continued)

$\begin{array}{llllllll}1964 & 115.07 & 290.27 & 2523 & 1100 & 37.9 & 0 & 1371 \\ 1965 & 115.44 & 280.30 & 2796 & 1107 & 35.0 & 1 & 1251 \\ 1966 & 101.77 & 273.67 & 2909 & 1107 & 34.0 & 1 & 1282 \\ 1967 & 119.78 & 270.63 & 3209 & 1304 & 33.2 & 0 & 1096 \\ 1968 & 124.59 & 245.65 & 3548 & 1312 & 41.9 & 0 & 1194 \\ 1969 & 134.33 & 325.70 & 4042 & 1366 & 93.1 & 0 & 1346\end{array}$

Source: Data Appendix 
1. Ashenfelter, Orley, G.E. Johnson and J.H. Pencaval. "Trade Unions and the Rate of Change of Money Wages in United States Manufacturing Industry". Review of Economic Studies. Vol. 39. 1972.

2. Ashenfelter, Orley, and J.H. Pencaval. "American Trade Union Growth, 19001960". Quarterly Journal of Economics. Vol. 83. 1969.

3. Bain, George S., and Farouk El Sheikh. Union Growth and the Business CycleAn Econometric Analysis. Oxford: Basil Blackwell. 1976.

4. Berg, Elliott. "Urban Rural Wages and the Nigerian Trade Union Movement, 1939-60: A Comment". Economic Development and Cultural Change. Vol. 17. July 1969.

5. Berg, Elliott. "Wages Policy and Employment in Less Developed Countries", In Charles Frank, Jr. and Richard C. Webb (eds.). Income Distribution and Growth in Less Developed Countries. Washington, D.C.: The Brookings Institution. 1970.

6. Dogas, D., and A.G. Hines. "Trade Union and Wage Inflation in the U.K.A Critique of Purdy and Zis". Applied Economics. Vol. 7. September 1975.

7. Erikson, J.R. "Wage Changes and Employment Growth in Latin American Industry". Williamstown, Mass.: Williams College (Centre for Development Economics). June 1970. Mimeographed. (Research Memorandum No. 36)

8. Gregory, Peter. The Impact of Institutional Factors on Urban Labor Markets. Washington, D.C.: World Bank. 1975. (World Bank Working Paper)

9. Hines, A.G. "Wage Inflation in the United Kingdom, 1948-1962: A Disaggregated Study". Economic Journal. Vol. 79. 1969.

10. Isbister, John. "Urban Wages and Employment in a Developing Country". Economic Development and Cultural Change. Vol.20. 1971.

11. Khan, M. Taufiq, and Asbjorn Bergan. "Measurement of Structural Change in the Pakistan Economy: A Review of the National Income Estimates 1949-50 to 1963-64". Pakistan Development Review. Vol. VI, No. 2. Summer 1966.

12. Kilby, Peter. "Industrial Relations and Wage Determination: Failure of the Anglo-Saxon Model". Journal of Developing Areas. Vol. 1. 1967.

13. Knight, J.B. "The Determination of Wages and Salaries in Uganda". Bulletin of Oxford Institute of Economics and Statistics. Vol. 19. 1967.

14. Lewis, W.A. The Theory of Economic Growth. London: Allen \& Unwin. 1954.

15. Mancke, R.B. "American Trade Union Growth, 1900-1960: A Comment". Quarterly Journal of Economics. Vol. 85. February 1971.

16. Morawitz, D. "Elasticities of Substitution in Industry: What Do We Learn from Econometric Estimates?" Washington, D.C.: IBRD. 1973. (Mimeographed)

17. Pakistan. Ministry of Finance. Finance Division. Economic Adviser's Wing. Pakistan Economic Survey 1974-75. Islamabad. 1975. 
18. Pakistan. Ministry of Finance. Planning and Development. Economic Affairs Division. Central Statistical Office. 25 Years of Pakistan in Statistics 1947-1972. Karachi. 1972.

19. Pakistan. Ministry of Finance. Planning and Economic Affairs. Statistical Division. Labour Force Survey. Karachi. (Various issues)

20. Pakistan. President's Secretariat. Economic Affairs Division. Central Statistical Office. Census of Manufacturing Industries 1959-60. Karachi. 1969.

21. Ramos, J. "A Heterodoxical Interpretation of the Employment Problem in Latin America”. World Development. Vol. II. July 1974.

22. Ramos, Joseph R. Labour and Development in Latin America. New York and London: Columbia University Press. 1970.

23. Sharpe, Ian G. "The Growth of Australian Trade Unions: 1907-1967". Journal of Industrial Relations. Vol. 13. June 1971.

24. Stern, Joseph. J. The Employment Impact of Industrial Investment - A Preliminary Report. Washington, D.C.: World Bank. (World Bank Working Paper No. 255)

25. Stiglitz, J.E. "Rural Urban Migration, Surplus Labor and the Relationship between Urban and Rural Wages”. East African Economic Review. Vol. 1. December 1969.

26. Strumthal, Adolf, and James S. Scoville (eds.). The International Labor Movement in Transition. Urbana: University of Illinois Press. 1973.

27. Todaro, M.P. "A Model of Labor Migration and Urban Employment in Less Developed Countries”. American Economic Review. Vol. 59. 1969.

28. Turner, H.A., and D.H.S. Jackson. "On the Determination of the General Wage Level - A World Analysis”. Economic Journal. Vol. 80. December 1970. 29. Webb, Richard C. "Wage Policy and Income Distribution in Developing Countries". In Charles Frank, Jr. and Richard C. Webb (eds.). Income Distribution and Growth in Less Developed Countries. Washington, D.C.: The Brookings Institution. 1970.

30. Wellisz, S. "Dual Economies, Disguised Unemployment and the Unlimited Supply of Labor". Economica. Vol. 35. 1968. 